$10-1-2021$

\title{
Cultural Capital and Argumentative Writing in English: Challenges and Strategies Used by EFL Student Teachers
}

\author{
Nunung Fajaryani \\ Universitas Jambi \\ Amirul Mukminin \\ Universitas Jambi, amirul.mukminin@unja.ac.id \\ Marzul Hidayat \\ Universitas Jambi \\ Muhaimin Muhaimin \\ Universitas Jambi \\ Eddy Haryanto \\ Universitas Jambi \\ See next page for additional authors \\ Follow this and additional works at: https://nsuworks.nova.edu/tqr \\ Digitadrt of the Bilingual, Multilingual, and Multicultural Education Commons, and the Social and \\ Benamora Sciences Commons \\ Network \\ Logo \\ Recommended APA Citation \\ Fajaryani, N., Mukminin, A., Hidayat, M., Muhaimin, M., Haryanto, E., Nazurty, N., Marzulina, L., Harto, K., \& \\ Habibi, A. (2021). Cultural Capital and Argumentative Writing in English: Challenges and Strategies Used \\ by EFL Student Teachers. The Qualitative Report, 26(10), 3029-3045. https://doi.org/10.46743/ \\ 2160-3715/2021.4784
}

This Article is brought to you for free and open access by the The Qualitative Report at NSUWorks. It has been accepted for inclusion in The Qualitative Report by an authorized administrator of NSUWorks. For more information, please contact nsuworks@nova.edu. 


\title{
Cultural Capital and Argumentative Writing in English: Challenges and Strategies Used by EFL Student Teachers
}

\begin{abstract}
Writing is one of the most difficult skills in language learning, particularly in learning English as a foreign language. The purposes of this qualitative study were to describe student teachers' challenges in composing argumentative writing and to explain how they encountered those challenges at one public university teacher-training program in Jambi, Indonesia. The theoretical framework of cultural capital was used to guide the study while the data were collected through demographic profiles and semi-structured in-depth interviews with student teachers. Due to the Covid-19 pandemic, we only had access to invite 12 students to participate in our study-they were six male and six female student teachers. All participants in this study had taken English academic writing subjects and had been familiar with argumentative English writing. To analyze the data, within-case and cross-case analyses were used. The results of the data analysis produced eight salient themes including insufficient vocabulary and grammar, giving arguments, writing habits, parents' occupation, the relationship between students, cognitive strategies, metacognitive strategies, and social strategies. The implications of the study are also discussed.
\end{abstract}

\section{Keywords}

argumentative writing, case study, cultural capital, Covid-19 pandemic, EFL student teachers

\section{Creative Commons License}

Creative

Commons

Chiswork is licensed under a Creative Commons Attribution-Noncommercial-Share Alike 4.0 International (t) Honconmercial

Authors

Nunung Fajaryani, Amirul Mukminin, Marzul Hidayat, Muhaimin Muhaimin, Eddy Haryanto, Nazurty

Nazurty, Lenny Marzulina, Kasinyo Harto, and Akhmad Habibi 


\title{
Cultural Capital and Argumentative Writing in English: Challenges and Strategies Used by EFL Student Teachers
}

\author{
Nunung Fajaryani, Amirul Mukminin, Marzul Hidayat, Muhaimin Muhaimin, \\ Eddy Haryanto, Nazurty Nazurty, and Akhmad Habibi \\ Universitas Jambi, Indonesia \\ Lenny Marzulina and Kasinyo Harto \\ Universitas Islam Negeri Raden Fatah Palembang, Indonesia
}

\begin{abstract}
Writing is one of the most difficult skills in language learning, particularly in learning English as a foreign language. The purposes of this qualitative study were to describe student teachers' challenges in composing argumentative writing and to explain how they encountered those challenges at one public university teacher-training program in Jambi, Indonesia. The theoretical framework of cultural capital was used to guide the study while the data were collected through demographic profiles and semi-structured in-depth interviews with student teachers. Due to the Covid-19 pandemic, we only had access to invite 12 students to participate in our study - they were six male and six female student teachers. All participants in this study had taken English academic writing subjects and had been familiar with argumentative English writing. To analyze the data, within-case and cross-case analyses were used. The results of the data analysis produced eight salient themes including insufficient vocabulary and grammar, giving arguments, writing habits, parents' occupation, the relationship between students, cognitive strategies, metacognitive strategies, and social strategies. The implications of the study are also discussed.
\end{abstract}

Keywords: argumentative writing, case study, cultural capital, Covid-19 pandemic, EFL student teachers

\section{Introduction}

Writing has an important role in our personal and professional lives. Writing is an act of communication, a purposeful means of addressing an audience. However, writing is currently viewed in academic circles as more than just a tool for communication. The ability to convey meaning proficiently in written texts is a crucial skill for academic and professional success (Crowhurst, 1990; Gray et al., 2005; Johnston \& Kotzee, 2011; Kellogg \& Raulerson, 2007; Weldy et al., 2014). One of the writing genres is argumentative writing which is considered the most common writing that students face in universities (Peloghitis, 2017). This genre of writing is important for university students to express their own points-of-view in academically appropriate forms and strategies (e.g., Karabacak \& Qin, 2010; Varghese \& Abraham, 1998). It is a form of writing in which the writer needs to convince readers of "the correctness of a central statement" (Hyland, 1990, p. 68). In writing an argumentative essay, a writer takes a position on an issue and gives supporting evidence to persuade someone else to accept, or at least consider the position (e.g., Hinkel, 2002; Oshima \& Hogue, 2007). The task of constructing a successful piece of argumentative writing is conceptually and 
structurally complex and demanding in comparison to composing in other genres. The writing of an argument places heavy cognitive and linguistic demands on the writer.

In the Indonesian context, "It is common that students at the university level are passive in the classroom" (Mukminin, 2012, p. 22). In terms of arguing with others in the classroom and in the educational setting more broadly, it is also not common. Students are likely to be silent and listen to their teachers during teaching and learning processes. "Their familiarity with "passive classroom" culture or teacher-centered instruction combined with their limited English ability kept them silent in class and made it difficult for them" (Mukminin, 2012, p. 22) to be active in the classroom. This may influence them in writing argumentative essays because English as a foreign language (EFL) students often lack experience in writing academic texts in their first language.

This issue is particularly relevant in Indonesia where there are limited opportunities for students to develop their academic writing skills, insufficient English language ability, and lack of academic writing socialization (Mukminin et al., 2015). These difficulties create significant obstacles for students, particularly for those who want to pursue higher education in English-speaking countries (Karabacak \& Qin, 2010; Stapleton, 2001). Additionally, a review of research on second-language writing has examined both second language argumentative texts and the strategies used in producing argumentative writing. The findings have indicated that English argumentative writing poses rhetorical constraints for secondlanguage writers (e.g., Cheng, 2010; Dastjerdi \& Samian, 2011; Liu, 2013; Xinghua \& Thompson, 2009). These studies focus on analysing rhetorical organization of students' written essays to measure students' ability in composing English argumentative tasks. Furthermore, the text-based research that has compared argumentative writing by native and non-native English speakers reveals rhetorical and textual differences, although some similarities have also been found (e.g., Hirose, 2003; Lv, 2015). The aims of Hirose's (2003) study and Lv's (2015) study are to compare the organizational structures of argumentative writing across different languages.

Additionally, the second-language writing research has examined the strategies that the second language writers employ to accomplish argumentative writing tasks (Peloghitis, 2017; Zhu, 2001). However, the second language (L2) writers' challenges with English argumentative writing have largely been approached from textual perspectives in which students are required to learn from argumentative texts. Regarding the second language (L2) writers' challenges with English argumentative writing, unfortunately, in Indonesia, not much research has examined students' perspectives in composing an argumentative writing except for one qualitative study conducted in Jambi, Indonesia by Mukmininet et al. (2015). Their study examined the experiences of Indonesian student teachers in English academic writing socialization. They focused on student teachers' perspectives and discussed constraints and solving strategies in academic writing in general. Despite the similarity of research site and research design between Mukminin et al.'s study (2015) and our study, the present study aimed to describe student teachers' struggles in writing an argumentative essay and to explore their strategies in English argumentative writing.

A number of the previous studies on second language argumentative writing in universities have focused on text-based research to diagnose students' competence in producing these texts (e.g., Cheng, 2010; Dastjerdi \& Samian, 2011; Liu, 2013; Xinghua \& Thompson, 2009). Additionally, Hirose (2003) and Lv (2015) conducted studies to explore the comparison of organizational structures of argumentative writing across different languages while Mu and Carrington (2007), Peloghitis (2017), and Zhu (2001) did studied the writing strategies used to accomplish an argumentative writing task. Previous research results have illustrated that more clarity is needed regarding the struggles that student teachers experienced in argumentative writing and the strategies that they used in the composing 
processes. The study was an attempt to fill the gaps in the literature by examining two research questions: (1) from the learners' perspective, what are the challenges faced by student teachers when performing an argumentative task in English? And (2) How do the student teachers manage their challenges in performing an argumentative task in English?

\section{Review of the Literature}

\section{The Theoretical Framework}

In this study, Bourdieu's (1986) theory of cultural capital was used as the theoretical framework. This theory exists in three forms (embodied, objectified, and institutionalized). First, Bourdieu (1986) argued that cultural capital is embodied in behaviors, interaction, and expression and in the command of valued cultural knowledge. In other words, in its embodied form, cultural capital is related to capability or skill which cannot be disconnected from its holder (person) due to a long-lasting disposition of mind, suggesting that the holder has been socialized with the skill that he or she needs to survive in her or his life. In the context of our study, our participants were supposed to have skills in writing an argumentative essay through teaching and learning processes that they had followed in their study. More specifically they had taken several courses related to writing skills during their college. Those courses such as Writing I, II, III, and IV were supposed to facilitate them to have skills in writing including in writing argumentative essays. Through taking those courses, writing skill is supposed to be represented in their academic life. The capability or skill in writing an argumentative essay should be embodied yet in their academic life and should be able to facilitate them to be successful in their educational processes. As a result, they might not face challenges to be able to write an argumentative essay.

Second, Bourdieu (1986) argued that in an objectified form, cultural capital is related to cultural things such as museums, libraries, monuments, historical sites, university syllabi, and texts. In the circumstances of our study, our participants were supposed to have targeted writing skills as they were provided with university syllabi, guided books, lectures, writing methods, and sample of writing for becoming successful in Writing I, II, III, and IV courses during their college. These "objectified" things (e.g., university syllabi) are intended to help them to have basic skills to write in English, particularly to write an argumentative essay as one of the targeted writing skills. Additionally, the "objectified" things are intended to provide them with skills so that they would be successful after taking writing courses.

Finally, in an institutionalized form, cultural capital is related to academic qualifications in the forms of credentials, which are obtained through training in a specific period. Bourdieu's (1986) cultural capital theory refers to a set of linguistic and cultural competencies of the dominant classes. In current societies with a system of formal education, the culture of the upper and middle classes may be transferred and passed through the educational system (e.g., curriculum, teaching methods, teachers, and facilities of the schools). To obtain cultural capital, a student must have the ability to receive and internalize it. Bourdieu (1986) looked at cultural capital as a set of values and non-financial resources such as the ability to talk, to act, and to think in particular ways and knowledge of music, art, and literature that are passed on from one generation to the next generation, binding the members of a cultural group together, and separating them from the members of other cultural groups (Sadovnik, 2007). Bourdieu (1986) argued that, besides economic factors, "cultural habits and dispositions inherited from" the family are fundamentally important to school or university success (Bourdieu \& Passeron, 1979, p. 14). From the perspectives of Bourdieu's (1986) cultural capital, the academic writing success of Indonesian student teachers in this study might be influenced by their ability to receive and internalize 
competencies in academic writing in English. More specifically, it determines how student teachers compose an argumentative writing in English. In our study, through the institutional curriculum and programs such as providing specific writing courses in every department or study program, participants (EFL student teachers) are trained to be able to possess writing skills which are reflected in their academic qualifications in the forms of credentials. The institutionalized curriculum and programs for our participants are expected to be able to provide them opportunities for competing with others after they graduate from the program. In short, through the cultural capital theory, we would like to look at how writing courses, programs, and curriculum are embodied, objectified, and institutionalized in order to help them succeed, particularly in this study, in writing an argumentative essay.

\section{Argumentative Writing}

The writing strategies are the processes that the writer goes through to produce the written form. A writer not only needs to know and apply the processes (strategies) of writing. According to Kroll (2003), writing is an activity that needs a process consisting of some stages. The stages are pre-writing, drafting, and revising through feedback from a teacher or from a peer. Furthermore, Harmer (2006) states that there is a process in writing that includes an interrelated set of recursive stages: (1) pre-writing which is related to a written planning process when students brainstorm, research, describe ideas, and often use diagrams; (2) arrangement which is related to students outlining the main points they want to express; (3) in the reviewing stage, students review, modify and rearrange the activities that they have done. They can either re-organize, add words, delete words according to the content that the students have achieved, or this is also called a draft fix; (4) editing, at this stage teachers fix and correct errors in grammar and edit to clarify sentences; and (5) publishing which is the last stage in the writing process, which can later be published in accordance with the wishes of writers.

Then, the next strategy is related to develop and organize ideas. Students need to know how to organize what they have learned about any topic or assignment into a wellstructured whole. In longer writing assignments, they need to know how to create a strong introduction that catches readers' interest; how to link ideas in logically connected paragraphs that contain enough supporting details; and how to conclude with a strong ending. The last strategy is about revising and editing ideas. Students need individual and group skills to assess their own work and the work of others for content, clarity, form, and style, and for errors in grammar, punctuation, and spelling. In our study, we would like to look how student teachers' experiences in composing argumentative writing and what challenges they faced and what strategies that they had to encounter those challenges at one public university teacher-training program in Jambi, Indonesia.

\section{Writing Skill and Its Challenges}

Writing is one of the most difficult skills in language learning, particularly in learning English as a foreign language and EFL student teachers face several challenges. Leki, (2001) categorizes two main challenges including (1) attested challenges and (2) more ideological challenges. First, the attested challenges are beyond issues of time and numbers of students and logistic tensions within the L2 English writing classroom itself which include developing an understanding of and a strategy for accommodating local needs. Furthermore, teacher training programs often do not include specific training in the teaching of writing (Kroll, 2003; Williams, 1995, in Leki, 2001). In other words, the attested challenges are not only related to the issues of time and numbers of students in the classroom, but also are the ones 
related to develop students' ability in writing based on their local needs. Topics should be the ones related to what L2 English students are familiar with so that they can build their ideas in writing an essay. For instance, providing writing topics that are related to students' backgrounds may be a good way to develop students' ability in writing in L2. The second set of challenges is ethical and ideological challenges. These kinds of challenges are related to writing in English as a foreign language regarding its relevance or irrelevance to students' educations, careers, or lives. Since English is a foreign or second language for students from non-English speaking countries, teaching writing for these kinds of students should have clear goals. EFL teachers who teach writing must decide exactly the purpose of teaching FL writing. For example, when they take some courses in writing (e.g., writing 1, writing 2) and fail that course, they are not allowed to continue to take the next courses in writing. This kind of failure can lower the students' motivation to learn English as a foreign language. Based on these kinds of challenges, in our study, we would like to look at what challenges our participants in writing an argumentative essay.

\section{The Context of the Study}

In a qualitative study, a researcher's background, his or her personal connections to the participants, his or her understandings of the matters being examined, and the vested positions that he or she brings to the subject (Patton, 1990) should be integrated in the study. A qualitative researcher should "explicitly identify their biases, values, and personal interest about their research topic and process" and access to the research participants (Creswell, 2007, p. 184). The first author for this study is a female Indonesian lecturer and has a doctoral degree in Education in one university in Indonesia. She formulated research goals and aims and administered the research. The second author holds a Ph.D. in Educational Leadership and Policy Studies from a US public university. He had experience and training in qualitative research by taking various courses at a graduate level, including qualitative research methods, qualitative data analysis, and research methods in education. He focused on writing, reviewing, and editing-prepared and/or presented published work. The third author holds a Ph.D. in Educational Leadership and Policy Studies from a US public university. He took various courses at a graduate level, including qualitative research methods, qualitative data analysis, and research methods in education. He helped with the methodology part of this study. The fourth author is a faculty member in one public university in Jambi, Indonesia. He holds a Ph.D. from Germany and focuses on science education and hard science. He helped with the methodology, including data collection and analyses. The fifth author is a faculty member in one public university in Jambi, Indonesia. He holds a Ph.D. from the Philippines and focuses his research on bilingual education. He helped with the methodology including data collection and analyses. The sixth author is a faculty member in one public university in Jambi, Indonesia who focuses her research on literature and theory. She helped with the methodology, particularly the data collection and analyses. The seventh and eighth authors are lecturers from Universitas Islam Negeri Raden Fatah Palembang who helped with the methodology, particularly the data collection and analyses. The last author is a senior lecturer from Universitas Jambi who took care of writing, reviewing, and editing-prepared and/or presented published work.

The authors' interest in exploring student teachers' challenges in composing argumentative writing and how they encountered those challenges was sparked by the fact that Indonesian student teachers are still struggling in composing argumentative writing in English as a foreign language. Additionally, we find that limited studies have been done in the Indonesian context. We decided to do this study as an attempt to provide information on student teachers' challenges in composing argumentative writing and how they encountered 
those challenges at one public university teacher-training program and how teachers and university and faculty level to help student teachers succeed in in composing argumentative writing in English as a foreign language. We are all interested in the topic is because many undergraduate student teachers are challenged to compose argumentative writing. We worked together in this project starting from identifying potential participants by making good connections with student teachers until finalizing the project.

\section{Methodology}

\section{Research Design, Site and Access, Sampling, and Participants}

In this study we used a qualitative case study design to examine the challenges of Indonesian student teachers in creating argumentative writing and how they encounter those challenges at one teacher training program in Jambi, Indonesia. Merriam (1998), Yin (2003), Stake (2005), and Denzin and Lincoln (2005) note that case study research is a qualitative approach in which the investigator explores a bounded system (a case) or multiple bounded system (cases) over time, through detailed and in-depth data collection involving multiple sources of information (e.g., interviews, audio visual material, and documents)., Additionally, Merriam (1998, p. 27) states that a qualitative case study is an intensive and holistic description, explanation, and analysis of "a bounded system" or phenomenon such as a person, a program, an institution, a process, a social unit, a group, and a policy. Creswell (1998) wrote that the bounded system can be bounded by time and place and the case can be a program, an activity, or individuals (Mukminin \& McMahon, 2013; Safitri et al., 2020).

We conducted the research at one public university specifically, English Department of Teacher Training Education in Jambi, Indonesia. Student teachers who have taken academic writing courses were the participants of this study. The access was obtained from the head of study program. The names of people, places, and research site were concealed through the use of pseudonyms in order to protect the rights of participants (Habibi et al., 2018; Mukminin et al., 2017). In this study, a purposeful sampling with a convenience case strategy was used. Creswell (2007, p. 126) wrote, "convenience cases, which represent sites or individuals from which researcher can access and easily collect data." We planned to recruit 15 to 25 participants in our study, however due to COVID-19 pandemic we only had access to invite 12 students (six male and six female) to participate in our study. We recruited all participants with the help of writing teachers (two teachers) at the research site. With the help of these teachers, we gave potential participants a demographic background survey and an informed consent form. All participants in this study had taken English academic writing subjects and had been familiar with argumentative English writing.

\section{Data Collection}

The primary data for this study were collected through semi-structured interviews which were conducted individually with each student teacher at one public university, specifically teacher training program in Jambi, Indonesia. Student teachers' essays constitute an additional source of data. The semi-structured interviews took place shortly after student teachers completed the assignment and ranged from approximately 45 to 60 minutes. The completed assignment was not used as the data for this study. However, the assignment was used as a starting point to interview our participants. In other words, after our participants finished their assignments from their teacher, we asked their time to be interviewed. The interview depended on the participants' time and willingness (Abrar et al., 2018). Some interviews were conducted in English and some in Indonesian, audio-taped, and directly 
transcribed verbatim. Additionally, to support the interview data, we also used a demographic background survey to obtain participants' backgrounds including gender, GPA, academic writing score, their preferences about writing, the familiarity of argumentative essay and whether they have ever written an argumentative essay.

The participants possessed a variety of characteristics regarding their gender, GPA, academic writing score, their preferences about writing, the familiarity of argumentative essay and whether they have ever written an argumentative essay. In this part, there were twelve participants getting involved in this study. Of 12 participants in our study, we had six male and female participants. By GPA, all of them had a GPA above 3.00. In terms of familiarity with argumentative writing, all participants reported that they were familiar with it. By experiences in writing argumentative, our participants reported that they had experiences with it. We named our participants with SS1, SS2, SS3, SS4, SS5, SS6, SS7, SS8, SS9, SS10, SS11, and SS12.

\section{Data Analysis and Representation}

In this study, we analysed the demographic data descriptively while the interview data were transcribed individually and then analysed. All the transcripts among the participants were analysed and compared to search for similarities and differences. The transcripts were reread line-by-line to find regularities and emerging themes and sub-themes among the data. Once all the interview data were coded and analysed, we started to identify how themes and sub-themes helped us to explain the research questions. During this process, we also removed or reduced overlapping and repetitive data. We used pattern coding to find mostly repetitive patterns of statements and consistencies among participants. This approach was chosen as it helped us to find patterns and regularity of participants' talks and statements. Miles and Huberman (1994, p. 56) wrote, "coding is analysis" and Johnson and Christensen (2008, p. 534) stated, "coding is a process of marking segments of data (usually text data) with symbols, descriptive words, or categories. For example, we listed potential and general themes and sub-themes based on the coding processes such as vocabulary and grammar, arguments, topic unfamiliarity, peer support, parents' occupation, practice and self-study, and learning motivation and learning facilities. Then, we discussed these themes and sub-themes with co-researchers to look at them in details by reading all the participants' interview data before we decided the final themes and sub-themes. More specifically, first we collected all potential statements or quotations related to each theme and sub-theme from each participant. Then, all of participants' statements or quotations were placed in the themes and sub-themes that we temporarily developed. This was done to make it easy to take their statements or quotations when we made final themes and sub-themes (Muazza et al., 2019; Mukminin, 2019). For example, for the theme, "Insufficient vocabulary and grammar," we listed all potential statements or quotations from twelve participants related to this theme that we coded earlier. Next, we reread all the statements line-by-line to find the most related ones and removed or reduced overlapping and repetitive ones.

\section{Ethical Consideration and Trustworthiness}

To ensure the credibility of the inquiry or the "trustworthiness" (Lincoln \& Guba, 1985 , p. 300) of this study, we conducted individual interviews lasting approximately one hour and to verify the accuracy of the data, findings, and interpretations (Creswell, 2007; Johnson \& Christensen, 2008). We did not only check with all the participants but also with our colleagues that served as member checking. Specifically, we returned all the interview data to all participants to get their feedback if they agreed or not with our data, findings, and 
interpretations. We would like to state that the manuscript entitled, cultural capital and argumentative writing in English: challenges and strategies used by EFL student teachers" had not undergone the IRB process as it is not a must in country like Indonesia. However, participants' decision to take part in this study was entirely voluntary and their identities were masked. More importantly, we provided our participants with an informed consent form that they had to sign and they were free to withdraw from participating in this study.

\section{Findings and Discussion}

We present the findings and major themes and their sub-themes that emerged and obtained from individual interviews. Five salient themes with their sub-themes to emerge were related to Challenges in performing an argumentative task in English, namely (1) insufficient vocabulary and grammar (content and development), (2) giving arguments (topic unfamiliarity and critical thinking skills-lack of support for reasons), (3) writing habits (practice and self-study), (4) parents' occupation (learning motivation and learning facilities), (4) the relationship between student and student (peer support). Additionally, three major themes related to strategies about how our participants managed their challenges in writing an argumentative task, namely (1) cognitive strategies, (2) metacognitive strategies, and (3) social strategies.

\section{Insufficient Vocabulary and Grammar: Content and Development}

Vocabulary and grammar are the two important elements in language. Having sufficient vocabulary and grammar knowledge for English as foreign language learners is important to develop content of their argumentative essays. We found that the first theme that emerged from participants' interviews is their "insufficient vocabulary and grammar." Their provisions of these language components influence them to organize the ideas and produce an argumentative writing. Participants in our study were challenged by their limited vocabulary and grammar as expressed by one of our participants:

The first is grammar... such as articles, auxiliary verbs, verb agreement, nouns, pronouns, adjectives, adverbs, and prepositions, it's very difficult and also about... maybe the rules.... If the lecturer does not give me hints or examples before I start to write, it makes me difficult to write an essay...the second is vocabulary. I have limited vocabulary to develop the content of my argumentative task... you know vocabulary challenges me a lot and it takes time for me to have more and more vocabulary in English. (SS 1)

Additionally, some other participants reported that they were afraid of making mistakes in grammar and avoiding the correct tenses when they were writing. For example:

In writing, I am afraid of making mistakes in grammar...particularly tenses... You know in English, there are a variety of tenses that we need to know such as present, past, and future and all of them are different from each other... (SS 10)

Additionally, developing ideas becomes one of the hardest parts experienced by the students when they are composing an argumentative essay, specifically if the task is a timed essay. Participants in this study mostly reported the same ideas about it, for example: "Maybe, I am lack of data to write from the topic, and the time maybe. I mean sometimes I have to write 
without a preparation in thirty minutes, or... in one hour, like that" (SS 4). Looking at the participants' statements above, it indicated that their background knowledge in English writing had influenced their ability to produce and develop their ideas into good sentences and paragraphs although they had taken academic writing courses.

\section{Giving Arguments: Topic Unfamiliarity}

Giving arguments is one of the key issues in writing an argumentative essay. A student or an individual must have strong background knowledge on the topic that he or she wants to write or focus on. In other words, she or he must be familiar with their topic of writing, if not; she or he may fail to present a strong argument in his or her argumentative essay. Participants generally indicated that they had struggles in writing an argumentative essay when they were given an unfamiliar topic by their lecturer during their writing course. Their unfamiliar topic hindered them to develop their argumentative essay. One of our participants reported, "If I am unfamiliar with the topic, it's one of my struggles maybe. So, I have to know first about the topic and then I will start to write" (SS 1). One female participant also reported the similar thing about the topic. Then, she realized that she would find a variety of topics to enrich her experience and knowledge related to the topics discussed. She commented:

As I said that I mean in this world there are so many topics that I do not know. So, when I got the topic that I do not know, I found it difficult. I am challenged because I have to write arguments about the unfamiliar topic... (SS 2)

In addition, one male student teacher replied that he had to explore all the things about the topics, and it took time. When he was in a timed essay, writing an unfamiliar topic was quite time consuming. As he mentioned in this excerpt, "The first challenge is about the topic. If it is unfamiliar, I must learn and it takes time to search or browse the idea, this is a timed essay" (SS 8). The findings above indicated that their unfamiliarity of the topic in writing is one of the constraints that they faced in writing an argumentative task. They also reported that they felt stressed when they were asked to write a timed essay.

\section{Critical Thinking Skills}

One of the essential points in writing an argumentative essay is writing arguments. Due to its special characteristics and features, this genre requires the writer to take stand or make claim and then give arguments or counterarguments as well. Two female participants revealed that they emphasized the complexity of the argumentative structure, "I think it's quite complicated because sometimes we give the reasons why. We have a topic and then we should make pros and cons" (SS 1).

Despite the uniqueness of argumentative essays, the writer should write convincing arguments and provide proofs and evidence. Participants in this study reported this constraint. For example, "Personally, it is challenging for me to write an argumentative essay because if I write and have lack of proofs or evidences, my argumentative writing is less convincing." The other participants shared the same idea, "An argumentative essay should be based on the concrete opinion, it is not subjective. Sometimes I give my opinions that I think they do not match with the facts; it is my own subjectivity" (SS 7). Thesis statement is the core in writing an argumentative essay since it reveals the writer's stance on the issue. One participant commented on the difficulty of writing thesis statement. As he expressed in the following 
excerpt, "I think writing an argumentative essay is challenging and complicated too. To write a good argumentative essay, I have to think the thesis statement" (SS 3). Additionally, two participants in this study reported that they had constraints to find supporting ideas as the evidence in their argumentative essays. Choosing and finding the evidence are also the hardest part in writing an argumentative essay.

\section{Writing Habits}

The participants in this study expressed that writing in Indonesian was easier than writing in English because they did not stress on the grammar rules. They also said that they were not worried about their vocabulary. For example, "When I write [an essay] in Indonesian, it is easier because it is the language that I speak fluently. I do not need to think about grammatical structures" (SS 1). Additionally, one participant of this study reported that she expressed the ideas in a written form because of their personality. She enjoyed writing as the way of communication with others. She reflected, "I like writing better than the other skills because I think I cannot give my opinion [speaking to others] directly" (SS 2). Participants in this study shared that they practiced their writing through some writing activities. They were used to self-study and practice in English. From participants' point of views, writing practices such as writing a blog or keeping a diary is the types of activities which support their writing skill. These activities also provide them with an opportunity for improving their language aspects. As mentioned by a female participant who enjoyed learning vocabulary in English since she was in elementary school.

\section{Parents' Occupation}

Results of the study indicated that parents' occupation influenced the success of students in learning English. Participants in this study reported similar things that emphasized the support from their parents related to learning motivation and learning facilities. A female student mentioned that she had an ambition to be an English lecturer in the future. She realized that to be an English teacher requires English competence including the mastery of language skills such as writing. Participants in this study also expressed that their parents support them in learning English not only in writing skill but also other skills. As one student reflected, additionally, participants in this study revealed that their parents provide them with learning facilities, for examples personal computer and internet to aid their learning. They said that they used those learning facilities for their academic works. More specifically, a female student shared the story about her parents' involvement in learning writing. She wanted to be a journalist, as a result her parents bought her books and discussed with her about her study. As she reflected, additionally, one male participant confessed that he got support from his parents since he was in junior high school. He said his parents taught him and his brother provided him with the internet access. Furthermore, he mentioned that he was able to get some information from the internet. As he reflected in the following excerpt,

The ideas have come from things that I've watched and that I've read from the internet. It is possible because my parents taught me when I was junior high school. Also, my brother provides me with internet connection at home, so I can explore things on the internet. (SS 8)

One male participant reported that his father is an English teacher, however the support he received only the learning facilities such as an English book. He had to be more independent in learning English. Interestingly, one female student expressed how her parents 
supported her in learning English by providing learning facilities even though her parents had a low-income salary. The results of the study indicated that parents' job influenced the way they motivated their children in learning English. Findings indicated that participants had supports from their parents in learning English. In fact, all the members of the family were getting involved to provide their children with motivation and learning facilities.

\section{The Relationship Between Student and Student}

This theme emerged from the results of study; it showed the condition in teaching and learning in academic writing instruction. Due to Indonesian culture, most all participants in this study mentioned that they were reluctant to ask their lecturers about writing problems. One student commented that he would feel stressed and frustrated when lecturers focused on their writing instruction on the product, suggesting that lecturers tended to assess students' writing achievement not based on the processes. Another male student was insecure when he wanted to ask some questions to the lecturers, so he chose to ask his senior about his writing problems. Additionally, one female student expected the lecturers to give written feedback on students' writing which might help students improve their writing. She also confessed that there was a gap between students and lectures in writing classroom. This may cause students hesitate to ask questions and share their ideas. In contrast, one participant reported that she asked written feedback from lecturers, "I think when I start to write, I will ask my lecturer, and then I think the lecturer gives me suggestion about my writing, e.g., is it cohesive or coherence with our topic" (SS 1)? From the participants' statements, they felt comfortable when they discussed their writing problems with their friends. The findings indicated that the relationship between student and student should be maintained in writing classroom instructions. This condition gives a positive effect on building collaborative learning, especially in writing.

\section{Challenges in Performing an Argumentative Task}

\section{Cognitive Strategies: Brainstorming and Making Outline}

The first theme emerged from the study was cognitive strategies. Participants in this study reported that they applied brainstorming about the topic before they wrote an argumentative writing. For example:

I think I have to have brainstorming first about the topic, what sentences or phrases that I am familiar with. Then I try to describe the topic... and then I read more about the topic to look at my position if I am for pros or cons. (SS 1)

Findings of this study indicated that participants applied cognitive strategies such brainstorming and making outline when they compose an argumentative writing. It can be inferred that participants in this study tended to be more independent to find effective ways in accomplishing their writing assignments.

\section{Metacognitive Strategies: Self-Editing and Revision}

The second theme emerged from this study was metacognitive strategies, suggesting that participants in this study had awareness to correct their mistakes in writing. As participants reported in the following excerpts: 
Usually, I will read my writing over and over again so that I can find the mistakes that I made. (SS 10)

Relevant or not, the development of the idea that I developed earlier is by checking the opinion that I have written down with points that are relevant to the topic before I usually revise it several times. Then, if it is relevant, I will use the idea. Then, the last problem is such as the structure of words, usually I have thought about what words to use in my argumentation essay. I think about this when the topic has been given or the points I have found. (SS 11)

Participants in this study commented that they checked again and again whether they had written in a cohesive and coherent way. Also, they decided the right choice of words to write in their essay. In addition, structure is one of their focuses when they are doing self-editing and revision.

\section{Social Strategies: Sharing with Friends}

The third theme emerged from this study was social strategies. Participants reported that they often discussed with their friends about their writing problems. They expected to have solutions when they got difficulties in writing an argumentative essay. Results of the study suggested that participants tended to solve their own writing problem, later they asked for help from their peers. For example:

I have someone to help me when I have difficulties to write an essay, I do not work by myself, so I have to ask someone to give me solutions or suggestions. I try to find solutions by myself but sometimes I feel that I am not confident. So I have to ask someone to give me solutions about my writing. (SS 1)

Based on the statement above, our participants in our study reported that they tried to find out the ways out by themselves when they had difficulties in writing an argumentative essay. However, if they were stuck, they would use their social strategies such as asking friends who are good at writing an argumentative essay or someone who knows a lot about writing an argumentative essay. This kind of strategy helped our participants in developing their argumentative essay.

\section{Discussion and Conclusions}

The purposes of this study were to describe student teachers' challenges in learning to compose English argumentative writing and to explain the strategies that they used to accomplish an argumentative writing assignment. The findings in this study indicated that there were eight major themes emerged including insufficient vocabulary and grammar, giving arguments, writing habits, parents' occupation, the relationship between student and student, cognitive strategies, metacognitive strategies, and social strategies. The results provide us with some insights into the challenges and strategies of Indonesian student teachers' learning for composing English argumentative writing.

Bourdieu's cultural capital theory (1986) argued that to obtain cultural capital, a student must have the ability to receive and internalize it. More specifically, Bourdieu (1986) looked at cultural capital as a set of values and nonfinancial resources such as the ability to talk, to act, and think in particular ways and knowledge that are passed on from one 
generation to the next generation, binding the members of a cultural group together, and separating them from the other cultural groups (Sadovnik, 2007). Participants in this study reported that they had limited linguistic aspects, argumentative skills, and writing experiences that influenced them in producing a good argumentative essay. Results of the study also indicated that participants-maintained students' relationship with their peers in English writing. Due to Indonesian culture, participants are reluctant to ask lecturers about their writing problems. In Indonesian classrooms, power distance and teacher-centered instructions are common things including in higher education. Such situations make students feel reluctant to discuss their writing problems with their teachers or lecturers inside and outside the classroom.

Moreover, results of the study revealed that insufficient vocabulary and grammar is a major cause of difficulty for EFL student teachers with limited writing experience when they composed an argumentative writing task. Participants' comments concerning their limited vocabulary and grammar are consistent with Ozfidan and Mitchells' study (2020). Due to their limited vocabulary and grammar, participants in this study reported that they had difficulties to organize and develop their ideas for an argumentative writing. Based on the interview results, participants expressed that they had more challenges in writing in English rather than in Indonesian, suggesting that participants' background knowledge in English writing had influenced their ability to produce and develop their ideas into good sentences and paragraphs although they had taken academic writing courses. Participants also reported that time constraint became one of the difficult parts in composing an argumentative essay. They were not able to organize their ideas into a coherent and cohesive essay.

From the participants' perspective, organizing and developing arguments were also the challenges that they faced when they were writing an argumentative essay. This finding is similar to previous studies on English argumentative writing (e.g., Al-Abed-Al-Haq \& Ahmed, 1994; Ozfidan \& Mitchell, 2020; Peloghitis, 2017; Zhu, 2001). These results suggest that organization and development of arguments can be challenging for students from different backgrounds, and not only from the textual perspectives, but also from the learners' own points-of-view. Students' ability in writing an argumentative essay depends much on their awareness of the topic discussed and their critical thinking skills (Mukminin et al., 2019). Participants in this study reported that an argumentative essay has its special features and strategies that are different from other types of genres. Due to its uniqueness, this type of genre requires students to take a stand and support their arguments with proofs and evidence to convince the readers.

Additionally, our results revealed that most of the participants did not have writing experiences in English. This condition influences them when they compose an argumentative writing. Participants as reported in this study also confirmed that writing is one of the hardest skills to learn, however they keep thinking writing skill is essential for their academic works and their professional career. This finding is also consistent with Mukminin et al.'s (2015) study which confirmed that student teachers still had constraints in producing English written forms. This study suggests that participants who had no strongly cultural background knowledge in English academic writing leading them to face a variety of problems related to write paragraphs and to relate one paragraph to other paragraphs.

Interestingly, participants in our study reported that they preferred to discuss and share with their peers about academic writing problems. However, they also said that they were reluctant to ask the lectures about their writing difficulties due to Indonesian culture. Additionally, maintaining a good relationship between student and student results in a good learning atmosphere, specifically in learning argumentative writing. Conversely, lecturers still must monitor and facilitate students' learning. This finding is consistent with what Mukminin et al. (2015) found that higher power distance accepted by the Indonesian society 
as part of their culture happened in Indonesian higher education which had made a gap between lecturers and participants inside and outside the classroom. Moreover, in terms of writing strategies, our findings indicated that participants in this study were resourceful learners. They employed various types of strategies without explicit instructions on writing strategies. Brainstorming and making outline were the most common approaches they used. Participants reported that they sometimes made a list of ideas and reasons based on what they read to help them to form arguments and counterarguments. Sharing ideas with friends was another important strategy that helped some participants to confirm whether an idea made sense or fitted structurally into the essay. This finding is in line with what Masbirorotni and Fajaryani (2020) found that dominantly student teachers applied cognitive strategies and metacognitive strategies in English writing.

The study aimed at extending research on English argumentative writing by describing student teachers' challenges in learning to compose an English argumentative writing and exploring the strategies that they used to accomplish an argumentative writing task. Eight salient themes and sub-themes emerged from this study were: insufficient vocabulary and grammar, giving arguments, writing habits, parents' occupation, the relationship between student and student, cognitive strategies, metacognitive strategies, and social strategies. The results of the study have potential implications for English writing instructions, specifically in Indonesian teacher training programs. First, the findings concerning students' challenges indicate a need for developing arguments and critical thinking skills. Thus, an important responsibility for lecturers is to help students develop these skills. Second, the findings of the study suggest that helping students develop cognitive strategies, metacognitive strategies, and social strategies perhaps should have a special place in writing instructions because these strategies may not be used automatically by students. Cognitive strategies, metacognitive strategies, and social strategies may be particularly beneficial for students who have limited writing experience even in their first language, like some of the participants in this study. Last, lecturers should have discussions (writing conference) with students in choosing the topics to write about as unfamiliar topics may become constraints for students to produce their argumentative writing.

\section{References}

Al-Abed-Al-Haq, F., \& Ahmed, S. E. A. (1994). Discourse problems in argumentative writing. Word Englishes, 13(3), 307-323.

Abrar, M., Mukminin, A., Habibi, A., Asyrafi, F., Makmur, M., \& Marzulina, L. (2018). "If our English isn't a language, what is it?" Indonesian EFL student teachers' challenges speaking English. The Qualitative Report, 23(1), 129-145. https://doi.org/10.46743/2160-3715/2018.3013

Bourdieu, P. (1986). The forms of capital. In J. G. Richardson (Ed.), Handbook of theory and research for the sociology of education (pp. 241-258). Greenword Press.

Bourdieu, P., \& Passeron, P. J. (1979). The inheritors: French students and their relations to culture. University of Chicago Press.

Cheng, F. W. (2010). Findings reasons for ESL/EFL argumentative writing. The Journal of ASIA TEFL, 7(1), 1-27.

Creswell, J. (1998). Qualitative inquiry and research design: Choosing among five traditions. Sage.

Creswell, J. (2007). Qualitative inquiry \& research design: Choosing among five traditions $\left(2^{\text {nd }}\right.$ ed.). Sage.

Crowhurst, M. (1990). Teaching and learning the writing of persuasive/argumentative discourse. Canadian Journal of Education, 15(4), 348-359. 
Dastjerdi, V. H., \& Samian, H. S. (2011). Quality of Iranian EFL learners' argumentative essays: Cohesive devices in focus. Mediterranean Journal of Social Sciences, 2(2), 65-76.

Denzin, N. K., \& Lincoln, Y. S. (Eds.). (2005). The Sage handbook of qualitative research $\left(3^{\text {rd }}\right.$ ed.). Sage.

Gray, F. E., Emerson, L., \& MacKay, B. (2005). Meeting the demands of the workplace: Science students and written skills. Journal of Science Education and Technology, 14(4), 425-435.

Habibi, A., Mukminin, A., Najwan, J., Sofwan, M., Haswindy, S., Marzulina, L., Sirozi, M., \& Harto, K. (2018). Investigating EFL classroom management in Pesantren: A case study. The Qualitative Report, 23(9), 2105-2123. https://doi.org/10.46743/21603715/2018.3117.

Habibi, A., Wachyunni, S., \& Husni, N. (2017). Students' perception on writing problems: A survey at one Islamic university in Jambi. Ta'dib: Journal of Islamic Education, 22(1), 96-108.

Harmer, J. (2006). How to teach writing. Pearson Longman Education.

Hinkel, E. (2002). Second language writers' text. Erlbaum.

Hirose, K. (2003). Comparing L1 and L2 organizational patterns in the argumentative writing of Japanese EFL students. Journal of Second Language Writing, 12(2), 181-209.

Hyland, K. (1990). A genre description of the argumentative essay. RELC Journal, 21(1), 6678.

Johnson, B., \& Christensen, L. B. (2008). Educational research: Quantitative, qualitative, and mixed approaches. Sage.

Johnston, R., \& Kotzee, B. (2011). Can't string a sentence together? UK employers' views of graduates' writing skills. Industry and Higher Education, 25(1), 45-52.

Karabacak, E., \& Qin, J. (2010). The analysis of Toulmin elements in Chinese EFL university argumentative writing. System, 38(3), 444-456.

Kellogg, R. T., \& Raulerson, B. A. (2007). Improving the writing skills of college students. Psychonomic Bulletin \& Review, 14(2), 237-242.

Kroll, B. (2003). Exploring the dynamics of second language writing. Cambridge University Press.

Leki, I. (2001). Material, educational, and ideological challenges of teaching EFL writing at the turn of the century. International Journal of English Studies, 1(2), 197-209.

Lincoln, Y. S., \& Guba, E. (1985). Naturalistic inquiry. Sage.

Liu, X. (2013). Evaluation in Chinese university EFL students' English argumentative writing: An appraisal study. Electronic Journal of Foreign Language Teaching, 10(1), 40-53.

Lv, G. (2015). Appraisal patterns in Chinese EFL argumentative essays. Theory and Practice in Language Studies, 5(4), 818-825.

Maharani, S., Fauziati, E., \& Supriyad, S. (2018). An investigation of writing strategies used by the students on the perspective language proficiency and gender. International Journal of Multicultural and Multi Religious Understanding, 5(5), 185-190.

Masbirorotni, M., \& Fajaryani, N. (2020). In search of commonly used language learning strategies by EFL students. Indonesian Research Journal in Education, 4(1), 171-186.

Merriam, S. B. (1998). Qualitative research and case study applications in education. Jossey-Bass.

Miles, M., \& Huberman, M. (1994). Qualitative data analysis: An expanded sourcebook. Sage.

Muazza, Mukminin, A., Rozanna, E. S., Harja, H., Habibi, A., Iqroni, D., Marzulina, L., Harto, K., Nurulanningsih. (2019). Caring the silenced voices from an Islamic 
boarding school-pesantren: Stories of volunteer teachers and policy implications. Dirasat: Human and Social Sciences, 46(3), 270-279.

Mukminin, A. (2012). Acculturative experiences among Indonesian graduate students in US higher education: Academic shock, adjustment, crisis, and resolution. The Excellence in Higher Education, 3(1), 14-36.

Mukminin, A., Ali, M. A., \& Ashari, M. J. (2015). Voices from within: Students teachers' experiences in English academic writing socialization at one Indonesian teacher training program. The Qualitative Report, 20(9), 1394-1407. https://doi.org/10.46743/2160-3715/2015.2280

Mukminin, A., Kamil, D., Muazza, M., \& Haryanto, E. (2017). Why teacher education? Documenting undocumented female student teachers' motives in Indonesia: A case study. The Qualitative Report, 22(1), 309-326. https://doi.org/10.46743/2160$3715 / 2017.2640$

Mukminin, A., \& McMahon, B. J. (2013). International graduate students' cross-cultural academic engagement: Stories of Indonesian doctoral students on an American campus. The Qualitative Report, 18(69), 1-19. https://doi.org/10.46743/21603715/2013.1473

Mukminin, A., Sari, S. R., Haryanto, E., Habibi, A., Hidayat, M., Marzulina, L., Nurullaningsih N., \& Ikhsan, I. (2019). They can speak English, but they don't want to use it: Teaching contents through English in a bilingual school and policy recommendations. The Qualitative Report, 24(6), 1258-1274. https://doi.org/10.46743/2160-3715/2019.3580

Mukminin, A. (2019). Acculturative experiences among indonesian graduate students in dutch higher education. Journal of International Students, 9(2), 488-510. doi:10.32674/jis.v0i0.265

Mu, C., \& Carrington, S. (2007). An investigation of three Chinese students' English writing strategies. ESL-EJ, 11(1), 1-23.

Oshima, A., \& Hogue, A. (2007). Introduction to academic writing ( ${ }^{\text {rd }}$ ed.). Pearson Longman.

Ozfidan, B., \& Mitchell, C. (2020). Detected difficulties in argumentative writing: The case of culturally and linguistically Saudi background students. Journal of Ethnic and Cultural Studies, 7(2), 15-29.

Patton, M. Q. (1990). Qualitative evaluation and research methods. Sage.

Peloghitis, J. (2017). Difficulties and strategies in argumentative writing qualitative analysis. In P. Clements, A. Krause, \& H. Brown (Eds.), Transformation in language education (pp. 399-406). JALT.

Sadovnik, A. (2007). Theory and research in the sociology of education. In A. Sadovnik (Ed.), Sociology of education: A critical reader (pp. 3-21). Routledge.

Safitri, N. T., Melati, Mukminin, A., \& Hidayat, M. (2020). Exposing English teachers' pedagogical content knowledge: A case of English language teaching practises in indonesia. International Journal of Scientific and Technology Research, 9(3), 850854.

Stake, R. (2005). Qualitative case studies. In N. K. Denzin \& Y. S. Lincoln (Eds.), The Sage handbook of qualitative research (pp. 443-466). Sage.

Stapleton, P. (2001). Assessing critical thinking in the writing of Japanese university students: Insights about assumptions and content familiarity. Written Communication, 18(4), 506-548.

Varghese, S. A., \& Abraham, S. A. (1998). Undergraduates arguing a case. Journal of Second Language Writing, 7(3), 287-306.

Weldy, T., Maes, J. D., \& Harris, J. D. (2014). Process and practice: Improving writing 
ability, confidence in writing, and awareness of writing skills' importance. Journal of Innovative Education Strategies, 3(1), 12-26.

Xinghua, L., \& Thompson, P. (2009). Attitudes in students' argumentative writing: A contrastive perspective. Language Studies Working Papers, 1(1), 3-15.

Yin, R. (2018). Case study research and applications: Design and methods. Sage.

Zhu, W. (2001). Performing argumentative writing in English: Difficulties, processes, and strategies. TESL Canada Journal, 19(1), 34-50.

\section{Author Note} Indonesia.

Dr. Nunung Fajaryani is a lecturer in the Faculty of Education, Universitas Jambi,

Amirul Mukminin is a professor in the Faculty of Education, Universitas Jambi, Indonesia. He holds a Ph.D. from Florida State University in Educational Leadership and Policy Studies and was a postdoctoral researcher at the University of Groningen, the Netherlands. Please direct correspondence to amirul.mukminin@unja.ac.id.

Marzul Hidayat, Ph.D., (Corresponding author) is an assistant professor in the Faculty of Education, Universitas Jambi, Indonesia. He holds a Ph.D. from Florida State University in Educational Leadership and Policy Studies. Please direct correspondence to mhiday@yahoo.com.

Muhaimin is a professor in the Faculty of Education, Universitas Jambi, Indonesia. Please direct correspondence to muhaimin_73@yahoo.de.

Eddy Haryanto, Ph.D. is an associate professor in the Faculty of Education, Universitas Jambi, Indonesia. Please direct correspondence to eharyanto@yahoo.com.

Nazurty is a professor in the Faculty of Education, Universitas Jambi, Indonesia.

Akhmad Habibi, Ph.D. is a lecturer in the Faculty of Education, Universitas Jambi, Indonesia.

Lenny Marzulina, M.Pd. is a faculty member of State Islamic University of Raden Fatah, Palembang, South Sumatra, Indonesia.

Kasinyo Harto is a professor in the State Islamic University of Raden Fatah, Palembang, South Sumatra, Indonesia.

Copyright 2021: Nunung Fajaryani, Amirul Mukminin, Marzul Hidayat, Muhaimin Muhaimin, Eddy Haryanto, Nazurty Nazurty, Akhmad Habibi, Lenny Marzulina, Kasinyo Harto, and Nova Southeastern University.

\section{Article Citation}

Fajaryani, N., Mukminin, A., Hidayat, M., Muhaimin, M., Haryanto, E., Nazurty, N., Habibi, A., Marzulina, L., \& Harto, K. (2021). Cultural capital and argumentative writing in English: Challenges and strategies used by EFL student teachers. The Qualitative Report, 26(10), 3029-3045. https://doi.org/10.46743/2160-3715/2021.4784 